\title{
Bilateral ankyloblepharon filiforme adnatum: a video documentation
}

\author{
Sujeeth Modaboyina (ㄷ), Deepsekhar Das 다 , Mandeep S Bajaj, \\ Chandradevi Shanmugam
}

Dr Rajendra Prasad Centre for Ophthalmic Sciences, All India Institute of Medical Sciences, New Delhi, India

\section{Correspondence to} Dr Deepsekhar Das; doc.deep.das@gmail.com

Accepted 12 July 2020

\section{DESCRIPTION}

An 11-month-old female child was brought to the ophthalmology outpatient department by her parents with the child being unable to open both of her eyes completely since birth. She had a fullterm, normal vaginal delivery, and there was no significant antenatal history. There was no history of similar illness in the family.

Her general physical examination was found to be normal. On ocular examination, both eyes were not opening completely, and there was a dense band connecting the upper and lower eyelids near the lateral canthus of the right eye and in the centre of the left eye. Rest of the anterior and posterior segments were within normal limits.

The child was systematically evaluated for underlying syndromes, all of which came out to be normal. A diagnosis of ankyloblepharon filiforme adnatum (AFA) was made, and she was planned for surgery.

After administering general anaesthesia, both of her eyelids were cleaned and thoroughly evaluated. An artery clamp was then used to clamp the ankyloblepharon, the band was then released, and excess skin was trimmed in the left eye; the same

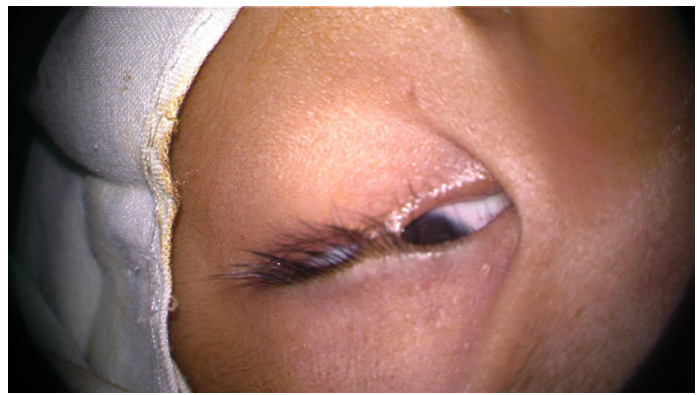

Figure 1 Picture showing ankyloblepharon filiforme adnatum in the right eye near the lateral canthus.

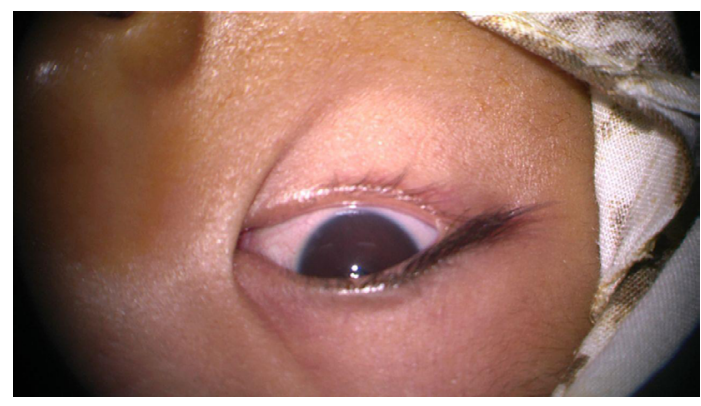

Figure 2 Picture showing ankyloblepharon filiforme adnatum in the left eye. procedure was repeated in the right eye (figures 1 and 2; video 1). Postoperative follow-up was unremarkable, and the child was doing well at 6 months after surgery.

AFA is a rare congenital anomaly which was first described by Von Hasner in $1881 .^{1}$ The incidence is 4.4 in 1 million births. ${ }^{2}$ The condition is usually associated with systemic malformations and has an autosomal dominant inheritance with varying degrees of penetrance. Sporadic cases have also been described in literature. ${ }^{3}$

The development of the eyelids involves multiple phases, one of the phases is where there is a fusion of the upper and lower eyelids. They remain fused till the fifth month of gestation and get separated by the seventh month. ${ }^{4}$ However, if there is a failure of separation, it gives rise to ankyloblepharon at the time of birth.

The length of these fused bands can be from 1 to $10 \mathrm{~mm}$ and the width varies from 0.3 to $0.5 \mathrm{~mm}$. They are always situated in between the cilia and openings of the tarsal gland and are composed of a central vascular connective tissue strand surrounded by pavement epithelium. When these bands are surgically disrupted, there is always a possibility of bleeding. There are reports in literature documenting the presence of subepithelial glands and muscle fibres within these bands. ${ }^{5}$

Although multiple theories have been hypothesised, the exact pathogenesis is not yet known. Hypothesised theories include a defect in separation, abnormal growth of the skin because of inflammation, the proliferation of connective tissue due to an epithelial defect in the fetal life, because of a fingernail trauma. However, the widely accepted theory is that of pure aberrance of development, due either to a temporary arrest of the growth of epithelium or, an abnormally rapid proliferation of mesoderm leading to the union at certain points of the mesenchyme of the lid folds without epithelial interposition. ${ }^{5}$ Most familial cases of AFA has an autosomal dominant pattern of inheritance and is associated with cleft lip and palate. Its commonly associated syndromes are: Edwards' syndrome (Trisomy 18), Hay-Wells syndrome (a variant of the ectrodactyly-ectodermal dysplasia-cleft lip-palate syndrome), popliteal pterygium syndrome (characterised by intercrural webbing of the lower limbs) and curly hair-ankyloblepharon-nail dysplasia . The condition has also been seen in association with hydrocephalus, meningocele, imperforate anus, bilateral syndactyly and cardiac problems. ${ }^{6}$ It has also been reported with infantile glaucoma 


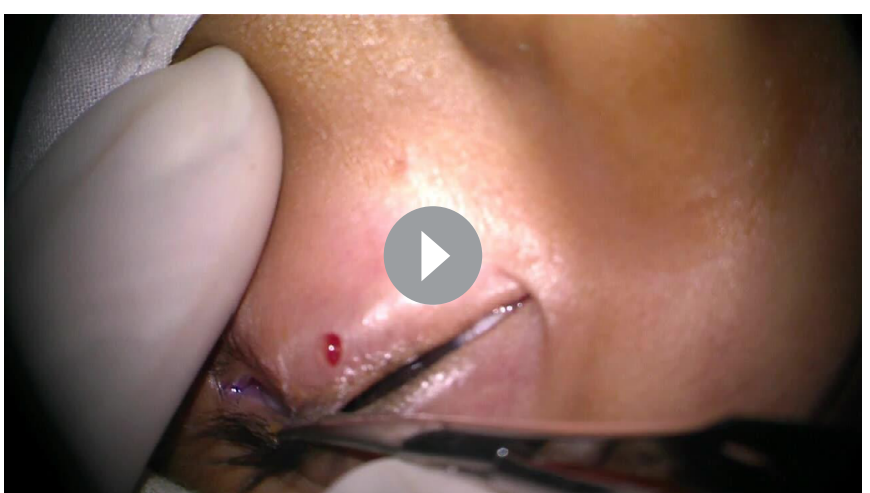

Video 1 Video showing examination of the right eye followed by the left eye and surgical release ofankyloblepharon in the left followed by the right eye.

and iridogoniodysgenesis. ${ }^{7}$ AFA was divided into 4 subgroups by Rosenman et al. ${ }^{8}$ According to which group I and II are sporadically inherited, and the remaining groups, group III and IV have autosomal dominant inheritance pattern. Group I have

\section{Patient's perspective}

My child was not able to open her eyes since birth. I am happy that the doctors helped her.

\section{Learning points}

- Anklyblepharon Filiforme Adnatum is a rare congenital eyelid abnormality where the eyelid margins remain fused to one another.

- If not operated, it can lead to amblyopia.

- Management involves clamping the band and cutting the band. no associated abnormalities, group II is associated with cardiac or central nervous system abnormalities, group III is associated with ectodermal syndrome while group IV is associated with cleft lip or cleft palate. ${ }^{8}$

AFA if not treated, can cause amblyopia. The management of AFA is simple and involves crushing the band with clamp or forceps followed by surgically excising it. ${ }^{9}$

In our case, the child was having a group I AFA and had a satisfactory outcome with surgery.

Contributors MSB and SM participated in the diagnosis and management of the patient. DD and CS participated in designing and preparing the manuscript.

Funding The authors have not declared a specific grant for this research from any funding agency in the public, commercial or not-for-profit sectors.

Competing interests None declared.

Patient consent for publication Parental/guardian consent obtained.

Provenance and peer review Not commissioned; externally peer reviewed.

\section{ORCID iDs}

Sujeeth Modaboyina http://orcid.org/0000-0002-1306-5722

Deepsekhar Das http://orcid.org/0000-0002-4446-0274

\section{REFERENCES}

1 Judge HV, Mott WC, Gabriels JAC. Ankyloblepharon filiforme adnatum. Arch Ophthal 1929;2:702-8.

2 Jain S, Atkinson AJ, Hopkisson B. Ankyloblepharon filiforme adnatum. Br J Ophthalmol 1997;81:705d.

3 Modi AJ, Adrianwalla SD. A multiple malformation syndrome with ankyloblepharon filiforme adnatum, with cleft lip and palate. Indian J Ophthalmol 1985;33:129-31.

4 Sharkey D, Marlow N, Stokes J. Ankyloblepharon filiforme adnatum. J Pediatr 2008; 152:594.

5 Duke-Elder S. System of ophthalmology. Vol. 3, Part 2. London: Henry Kimpton, 1964: 869.

6 Gruener AM, Mehat MS. A newborn with ankyloblepharon filiforme adnatum: a case report. Cases J 2009;2:8146.

7 Scott MH, Richard JM, Farris BK. Ankyloblepharon filiforme adnatum associated with infantile glaucoma and iridogoniodysgenesis. J Paediatr Ophthalmol Strabismus:19943193-5.

8 Rosenman Y, Ronen S, Eidelman Al, et al. Ankyloblepharon filiforme adnatum: congenital eyelid-band syndromes. Am J Dis Child 1980;134:751-3.

9 Chakraborti C, Chaudhury KP, Das J, et al. Ankyloblepharon filiforme adnatum: report of two cases. Middle East Afr J Ophthalmol 2014;21:200-2.

Copyright 2020 BMJ Publishing Group. All rights reserved. For permission to reuse any of this content visit

https://www.bmj.com/company/products-services/rights-and-licensing/permissions/

BMJ Case Report Fellows may re-use this article for personal use and teaching without any further permission.

Become a Fellow of BMJ Case Reports today and you can:

- Submit as many cases as you like

- Enjoy fast sympathetic peer review and rapid publication of accepted articles

- Access all the published articles

- Re-use any of the published material for personal use and teaching without further permission

Customer Service

If you have any further queries about your subscription, please contact our customer services team on +44 (0) 2071111105 or via email at support@bmj.com.

Visit casereports.bmj.com for more articles like this and to become a Fellow 